\title{
Model Inquiry dengan Media Diorama untuk Meningkatkan Hasil Belajar Siswa
}

\author{
Ibnu Dwi Kustadiyono
}

\author{
SMP Negeri 1 Taliwang, Jl. Undru, Kuang, Taliwang, Kabupaten Sumbawa Barat, Nusa Tenggara \\ Barat, Indonesia 84455 \\ *Corresponding Author e-mail: ibnukus71@gmail.com
}

Received: February 2020; Revised: March 2020; Published: March 2020

\begin{abstract}
Abstrak
Tujuan penelitian ini adalah meningkatkan hasil belajar IPA pada siswa melalui penerapan model inquiry dengan media diorama yang mempunyai ciri memberikan stimulus atau rangsangan, pengajuan hipotesis, pengumpulan data, dan presentasi. Penelitian tindakan kelas (PTK) dengan dua siklus pelaksanaan dengan tahap-tahap (1) perencanaan tindakan, (2) pelaksanaan tindakan, (3) observasi dan (4) refleksi dilakukan dalam penelitian ini. Subjek dalam penelitian ini adalah 26 siswa kelas VII-1 SMPN 1 Taliwang Sumbawa Barat dengan materi ajar Klasifikasi Makhluk Hidup khususnya Hewan. Instrumen penelitian berupa lembar observasi guru, lembar observasi siswa, dan tes evaluasi digunakan dalam penelitian ini untuk mengumpulkan data melalui metode tes, observasi dan dokumentasi. Data hasil penelitian dianalisis secara deskriptif untuk menentukan keterlaksanaan pembelajaran dan peningkatan hasil belajar siswa. Hasil penelitian menunjukkan peningkatan prestasi hasil belajar siswa setelah diberi tindakan pada setiap siklus pelaksanaan dalam penelitian ini. Berdsarkan hasil penelitian dapat disimpulkan bahwa model inquiry dengan media diorama dapat meningkatkan hasil belajar siswa.
\end{abstract}

Kata Kunci: Model inquiry, Media diorama, hasil belajar, Klasifikasi Makhluk Hidup

\section{Model Inquiry with Media Diorama to Improve Student Learning Outcomes}

\begin{abstract}
The purpose of this study is to improve student learning outcomes of science through the application of inquiry models with diorama media that have the characteristics of providing stimulus or stimulation, submission of hypotheses, data collection, and presentations. Classroom action research (CAR) with two cycles of implementation with stages (1) action planning, (2) action implementation, (3) observation and (4) reflection conducted in this study. Subjects in this study were 26 students of class VII-1 SMPN 1 Taliwang Barat West Sumbawa with teaching material Classification of Living Things, especially Animals. Research instruments in the form of teacher observation sheets, student observation sheets, and evaluation tests were used in this study to collect data through the test, observation and documentation methods. The research data were analyzed descriptively to determine the effectiveness of learning and improvement of student learning outcomes. The results showed an increase in student learning achievement after being given action in each cycle of implementation in this study. Based on the results of the study it can be concluded that the inquiry model with diorama media can improve student learning outcomes. Keywords: Inquiry model, Media diorama, learning outcomes, Classification of Living Things
\end{abstract}

How to Cite: Kustadiyono, I., D. (2020). Model Inquiry dengan Media Diorama untuk Meningkatkan Hasil Belajar Siswa. Jurnal Penelitian dan Pengkajian Ilmu Pendidikan: e-Saintika, 4(1), 54-61. doi:https://doi.org/10.36312/e-saintika.v4i1.180 


\section{PENDAHULUAN}

Konsep Pembelajaran IPA Terpadu menuntut adanya situasi lebih nyata dengan penekanan pada konstruksi korelasi antara ilmu-ilmu alam dengan pengetahuan yang dimiliki serta penerapan pada lingkungan otentik yang telah diimplementasikan dalam kurikulum sekolah, baik sekolah dasar maupun sekolah menengah. Pengetahuan yang dimiliki seseorang selalu bermula dari "bertanya". Sebelum tahu makhluk hidup, seseorang bertanya " apakah makhluk hidup itu?", "ada berapa jenis makhluk hidup?". Bertanya baik dilakukan oleh guru maupun siswa, merupakan ciri utama pembelajaran IPA Terpadu. Bertanya dalam pembelajaran IPA Terpadu dipandang sebagai kegiatan guru untuk mendorong, membimbing dan menilai kemampuan berpikir siswa. Selain itu bagi siswa, kegiatan bertanya merupakan bagian penting dalam melaksanakan pembelajaran yang berbasis inkuiri, yang menggali informasi, mengkonfirmasikan apa yang sudah diketahui, dan mengarahkan perhatian pada aspek yang belum diketahuinya.Apabila bertanya merupakan ciri utama pembelajaran IPA Terpadu maka menemukan merupakan bagian inti dari kegiatan pembelajaran tersebut. Pengetahuan dan keterampilan yang diperoleh siswa diharapkan bukan hasil mengingat seperangkat fakta-fakta, tetapi hasil dari menemukan dan menggeneralisasi sendiri. Oleh sebab itu, dalam pembelajaran IPA Terpadu guru harus selalu merancang kegiatan yang merujuk pada kegiatan menemukan, apapun materi yang diajarkannya.

Model pembelajaran terpadu merupakan model pembelajaran yang mendekatkan pada dunia nyata yaitu bersifat interaktif serta dapat membawa 3 cakrawala baru lintas keilmuan dan persoalan dalam keterkaitan yang bermakna menuju wilayah studi yang luas. Pembelajaran IPA Terpadu di SMP, yaitu pembelajaran yang menghubungkan pelajaran fisika, kimia, dan biologi, menjadi suatu bentuk pembelajaran yang tidak berdiri sendiri-sendiri, melainkan menjadi suatu kesatuan yang diajarkan secara simultan. Peserta didik dapat memperoleh pengalaman langsung melalui pembelajaran IPA terpadu, sehingga dapat menambah kekuatan untuk menerima, menyimpan, dan memproduksi kesan-kesan tentang halhal yang dipelajarinya. Model pembelajaran terpadu pada hakikatnya merupakan suatu pendekatan pembelajaran yang memungkinkan peserta didik baik individual maupun kelompok aktif mencari, menggali, dan menemukan konsep serta prinsip secara holistik dan otentik.

Pembelajaran IPA Terpadu di SMPN 1 Taliwang Sumbawa Barat pada tahun 2018 khususnya di kelas VII masih menggunakan metode belajar secara konvensional, hal ini disebabkan karena kurang memaksimalkan model pembelajaran yang ada oleh guru sehingga pencapaian hasil belajar siswapun masih dalam kategori cukup dan semangat belajar siswa kadangkala mengalami kejenuhan. Secara umum aktivitas dan hasil belajar siswa belum sesuai yang diharapkan. Disisi lain tinjauan terhadap guru sendiri biasanya ada materi yang susah diajarakan, artinya disamping materinya agak susah juga media pembelajaran yang digunakan masih kurang memadai. Adanya faktor-faktor internal yang dimiliki siswa seperti: gaya belajar, kemampuan awal, gaya berfikir, motivasi berprestasi, kemampuan abstrak, sikap ilmiah dan gaya belajar yang dimiliki siswa belum diperhatikan oleh guru. Padahal kesemua faktor tersebut seharusnya mendapat perhatian dari guru sehingga guru secara psikologis dapat mengetahui keadaan anak dalam menerima pembelajaran dan faktor-faktor tersebut diharapkan dapat mempengaruhi pula proses penerimaan anak dalam menerima pembelajaran fisika dan akhirnya dapat pula mempengaruhi prestasi 
belajar siswa.

Penggunaan model inquiry dengan media diorama, materi yang disampaikan lebih menarik. Siswa akan menjadi lebih aktif dan mudah memahami materi pembelajarannya karna terdapat contoh konkritnya. Guru harus selalu merancang kegiatan yang merujuk pada kegiatan menemukan, apapun materi yang diajarkannya Menurut Trianto (2007) Pengetahuan dan keterampilan yang diperoleh siswa diharapkan bukan hasil mengingat seperangkat fakta-fakta, tetapi hasil dari kegiatan menemukan sendiri. Oleh karena itu peneliti tertarik untuk melakukan suatu penelitian tindakan kelas dengan Menggunakan Model Inquiry dengan Media Diorama.

Penelitian ini pernah dilakukan sebelumnya sebagaimana penelitian yang telah dilakukan oleh Wijayanti (2017) melakukan penelitian terkait dengan judul Peningkatan Hasil Belajar IPA Materi Ciri-ciri Makhluk Hidup Menggunakan Model Pembelajaran Inquiry Pada Siswa Kelas VIII MTsN Darul Ulum Reksosari Kecamatan Suruh Kabupaten Semarang Tahun Pelajaran 2016/2017. Hasil penelitian menunjukkan adanya peningkatan hasil belajar siswa kelas VIII MTsN Darul Ulum Reksosari dalam pembelajaran IPA menggunakan model pembelajaran inkuiri baik pada siklus I maupun siklus II. Hasil belajar mengalami peningkatan dari kondisi awal. Di Pihak lain Nudhar (2018) melakukan penelitian terkait dengan judul Peningkatan Hasil Belajar IPA Materi Siklus Air Menggunakan Model Inquiry dan Media Diorama Pada Siswa Kelas V MI Kumpulrejo 02 Salatiga Tahun Pelajaran 2018/2019. Hasil penelitian menunjukkan dengan menggunakan model inquiry dan Media Diorama dapat meningkatkan hasil belajar di kelas V MI Kumpulrejo 02 Salatiga Tahun Pelajaran 2018/2019. Terbukti setelah dibandingkannya nilai pre tes dan post tes hasil belajar siswa meningkat.

Persamaan dari penelitian yang dilakukan penulis dengan penelitian yang dilakukan oleh Wijayanti dan AN Nudhar sama-sama menggunakan Penelitian Tindakan Kelas. Perbedaan penelitian kali ini dengan penelitian terdahulu terdapat pada jumlah variabel penelitian, jumlah siswa yang akan di teliti, kajian materi, dan tempat penelitian. Jadi, peneliti tertarik untuk meneliti kembali penelitian yang sejenis guna membuktikan teori yang sudah ada. Berdasarkan permasalahan tersebut, untuk menciptakan pembelajaran yang bermakna adalah dengan mencoba menerapkan model pembelajaran inquiry dengan media diorama

Tujuan diadakan penelitian tindakan kelas ini adalah (1) untuk mengetahui penggunaan model Inquiry dengan media diorama dapat meningkatkan hasil belajar IPA materi klasifikasi makhluk hidup pada siswa kelas VII di SMPN 1 Taliwang, (2) mendorong siswa untuk dapat meningkatkan kemampuan berfikir tentang IPATerpadu dan membuat siswa untuk lebih termotivasi dalam belajar IPA, dan (3) guru dapat memberikan gambaran tentang pengelolaan, perencanaan dan pelaksanaan pembelajaran dengan menggunakan model inquiry dengan media diorama sehingga belajar IPA menjadi lebih menarik, asyik dan menyenangkan.

\section{METODE}

Penelitian ini merupakan Penelitian Tindakan Kelas yang dilaksanakan di SMPN 1 Taliwang, Kabupaten Sumbawa Barat, Provinsi Nusa Tenggara Barat tahun pelajaran 2019/2020, dan waktu penelitian pada awal semester I tahun 2019 dengan mengacu pada Kurikulum 2013 yang diterapkan di SMPN 1 Taliwang Sumbawa Barat dengan mengambil populasi dan sampel adalah seluruh siswa kelas VIISMPN 1 
Taliwang Sumbawa Baratsebanyak tujuh kelas paralel yaitu kelas VII-1, VII-2, VII-3, VII-4, VII-5, VII-6 dan VII-7 yang berjumlah 213 orang. Pada penelitian ini hasil undian diambil dari tujuh kelas paralel yang semuanya memiliki perlakuan yang sama, karena ketujuh kelas menggunakan kurikulum dan materi yang sama, serta memiliki kemampuan yang sama pula, dari undian hanya diambil satu kelas kelas dan hasil undian di peroleh kelas VII-1 sebagai obyek penelitiandengan jumlah siswa pada saat penelitian 26 orang ( $\mathrm{P}=20$ orang ; dan $\mathrm{L}=6$ orang ).

Rancangan Penelitian ini meliputi pembuatan rencana pelaksanaan pembelajaran (RPP) yang akan dijadikan Penelitian yaitu kompetensi dasar (KD): Tentang Klasifikasi Makhluk Hidup. Penelitian ini terdiri dari beberapa siklus sesuai dengan yang direncanakan/ditargetkan. Masing-masing siklus meliputi : Perencanaan, Tindakan, Pengamatan dan Refleksi. Hal ini sesuai pendapat Suharsimi dalam Suhardjono dan Supardi (2007) PTK dilaksanakan dalam bentuk siklus berulang yang di dalamnya terdapat empat bahasan utama kegiatan yaitu perencanaan, tindakan, pengamatan dan refleksi.

Instrumen penelitian yang digunakan dalam penelitian ini adalah : lembar observasi/pengamatan, soal pre test, soal post test dan soal tes akhir siklus. Peneliti dalam melakukan penelitian dibantu teman sejawat yang merupakan guru IPA sebagai observer.

Terdapat dua jenis variable dalam penelitian ini: (1) Variabelharapan yaitu Meningkatkan hasil belajar siswa terhadap mata pelajaran IPA Materi Klasifikasi Makhluk Hidup pada Siswa Kelas VII-1 SMP Negeri 1 Taliwang, Kabupaten Sumbawa Barat dan (2) Variabel Tindakan yaitu : Penerapan modelpembelajaran inquiry dengan media diorama.

Sumber dan Teknik Analisa Data dari siswa yaitu : data tentang peningkatan hasil belajar siswa dalam pelajaran IPA. Di buktikan dengan hasil belajar siswa yang semakin meningkat di setiap siklusnya. Dan dari guru yaitu : data tentang penerapan model pembelajaran inquiry dengan media diorama.

Teknik Analisa Datayang digunakan adalah (1) data kuantitatif, analisis ini akan digunakan untuk menghitung besarnya peningkatan hasil belajar siswa dengan menerapkan media visual menggunakan data berupa jumlah nilai rata-rata nilai, prosentase (\%), data tabel dan grafik dengan menggunakan excel dan (2) data kualitatif, teknik analisis ini akan digunakan untuk memberikan gambaran hasil penelitian secara ; reduksi data, sajian deskriptif, dan penarikan simpulan

Data hasil tes siswa dinyatakan dalam nilai kemampuan menyelesaikan soal IPA dalam rentang 0-100. Setelah memperoleh data hasil belajar, maka data tersebut dianalisis untuk mencari ketuntasan belajar individu dan klasikal. Setiap siswa dalam proses belajar mengajar dikatakan tuntas apabila memperoleh nilai $\geq 73$ dan sesuai dengan petunjuk teknis penilaian kelas dikatakan tuntas secara klasikal terhadap materi yang diberikan jika mencapai $\geq 85 \%$.

Data yang didapatkan dari hasil observasi dan evaluasi pada setiap siklus selanjutnya dianalilis dengan metode-metode yang telah diterapkan sebelumnya . Adapun pelaksanaan pembelajaran konsep klasifikasi makhluk hidup dengan metode inquiry dengan media diorama dikelas VII-1 SMPN 1 Taliwang di analisis secara deskriptif. 


\section{HASIL DAN PEMBAHASAN}

Penelitian ini menggunakan pembelajaran melalui penggunaan model Inquiry dengan media diorama. Tujuan yang diharapkan pada pertemuan pertama dalam pembelajaran di SMP Negeri 1 Taliwang adalah meningkatkan hasil belajar siswa pelajaran IPAdi kelas VIII-1 dengan jumlah siswa 26 orang.

Pelaksanaan tindakan dalam penelitian dilakukan sebelumnya pra siklus dengan memberikan tes kemampuan awal dan 2 siklus dalam penelitian yang terdiri dari 5 kali pertemuan. Waktu yang digunakan setiap kali pertemuan adalah 3 x 40 menit. Pertemuan pertama dilaksanakan pada tanggal 2 s.d 9 Agustus 2019 dan pertemuan kedua pada tanggal 9 s.d 16 Agustus 2019, dan pertemuan ke tiga 16 s.d 23 Agustus 2019 dan Pertemuan ke 4 tanggal 23-30 Agustus 2019, Kelima perbaikan dan Penggandaan Laporan. Penelitian tindakan kelas dilaksanakan sesuai dengan prosedur rencana pembelajaran dan skenario pembelajaran.

Deskripsi Pra Siklus

Data yang diperoleh dari observasi menunjukkan bahwa hasil tes kemampuan awal siswa pada mata pelajaran IPA materi Klasifikasi Mahkluk hidup masih banyak yang belum dapat mencapai KKM sebesar 73.

Deskripsi Siklus I

Tahap perencanaan

Pada tahap ini peneliti mempersiapkan perangkat pembelajaran yang terdiri dari rencana pelaksanaan pembelajaran, soal tes siklus I dan alat-alat pengajaran yang mendukung.

Tahap kegiatan dan pelaksanaan

Pelaksanaan kegiatan belajar mengajar untuk siklus I dilaksanakan pada tanggal 9 s.d 16 Agustus 2019 di SMP Negeri 1 Taliwang tahun pelajaran 2019-2020. Dalam hal ini peneliti bertindak sebagai guru. Adapun proses belajar mengajar mengacu pada rencana pelajaran dengan memperhatikan revisi pada pra siklus, sehingga kesalahan atau kekurangan sebelumnya tidak terulang lagi pada siklus I.

Tahap Pengamatan dan Pengumpulan Data

Pengamatan (observasi) dilaksanakan bersamaan dengan pelaksanaan belajar mengajar. Pada akhir proses belajar mengajar siswa diberi tes formatif I dengan tujuan untuk mengetahui tingkat keberhasilan siswa dalam proses belajar mengajar yang telah dilakukan. Instrumen yang digunakan adalah tes formatif I. nilai rata-rata yang dicapai siswa pada siklus I mencapai 73,57 dari 26 siswa kelas VII-1 SMPN 1 Taliwang, Tahun Pelajaran 2019/2020 dengan nilai standar KKM $73=69,23$ \% (18 siswa) yang tuntas, sedangkan 30,77 \% (8 siswa) belum tuntas, siklus I secara klasikal pembelajaran belum tuntas, meskipun siswa yang memperoleh nilai $\geq 73$ (nilaiKKM) sudah mencapai 69,23 \% dari jumlah siswa secara keseluruhan. Namun hasil presentase belum mencapai indikator keberhasilan yaitu $\geq 85 \%$ dari jumlah seluruh siswa tuntas belajarnya, jadi peneliti harus melaksanakan siklus selanjutnya yaitu siklus II pada waktu yang telah ditentukan.

Deskripsi Siklus II

Tahap perencanaan

Pada tahap ini peneliti mempersiapkan perangkat pembelajaran yang terdiri dari rencana pelaksanaan pembelajaran, soal tes siklus II dan alat-alat pengajaran yang mendukung.

Tahap kegiatan dan pelaksanaan 
Pelaksanaan kegiatan belajar mengajar untuk siklus I dilaksanakan pada tanggal 16 s.d 23 Agustus 2019 di SMP Negeri 1 Taliwang tahun pelajaran 2019-2020. Dalam hal ini peneliti bertindak sebagai guru. Adapun proses belajar mengajar mengacu pada rencana pelajaran dengan memperhatikan revisi Siklus I, sehingga kesalahan atau kekurangan sebelumnya tidak terulang lagi pada siklus II.

Tahap Pengamatan dan Pengumpulan Data

Pengamatan (observasi) dilaksanakan bersamaan dengan pelaksanaan belajar mengajar. Pada akhir proses belajar mengajar siswa diberi tes Siklus II dengan tujuan untuk mengetahui tingkat keberhasilan siswa dalam proses belajar mengajar yang telah dilakukan. Instrumen yang digunakan adalah tes Siklus II,. nilai siklus II menunjukkan bahwa nilai rata-rata yang dicapai siswa pada siklus I mencapai 78,84 dari 26 siswa kelas VII-1 SMPN 1 Taliwang, Tahun Pelajaran 2019/2020 dengan nilai standar KKM $73=100$ \% (26 siswa) yang tuntas, sedangkan belum tuntas tidak ada, siklus II secara klasikal sudah tuntas karena siswa yang memperoleh nilai $\geq 73$ (nilai KKM) sudah mencapai $100 \%$ dari jumlah siswa secara keseluruha, dan sudah mencapai indikator keberhasilan yaitu $\geq 85 \%$ dari jumlah seluruh siswa tuntas belajarnya, pembelajaran pada siklus II sudah berhasil sehingga penelitian dihentikan sampai siklus II. Berikut disajikan pada Tabel 1 dan Gambar 1 rekapitulasi hasil belajar siswa berdasarkan siklus penelitian.

Tabel 1. Rekapitulasi Hasil Belajar Siswa Pra Siklus, Siklus I, Siklus II

\begin{tabular}{lllll}
\hline Siklus & Rata-rata & Kategori & Jumlah & Presentase \\
\hline Pra Siklus & 67.88 & Tuntas & 10 & $38,46 \%$ \\
& & Belum Tuntas & 16 & $61,53 \%$ \\
Siklus I & 73.58 & Tuntas & 18 & $69,23 \%$ \\
& & Belum Tuntas & 8 & $30,76 \%$ \\
Siklus II & \multirow{2}{*}{80,96} & Tuntas & 26 & $100 \%$ \\
& & Belum Tuntas & 0 & $0 \%$ \\
\hline
\end{tabular}

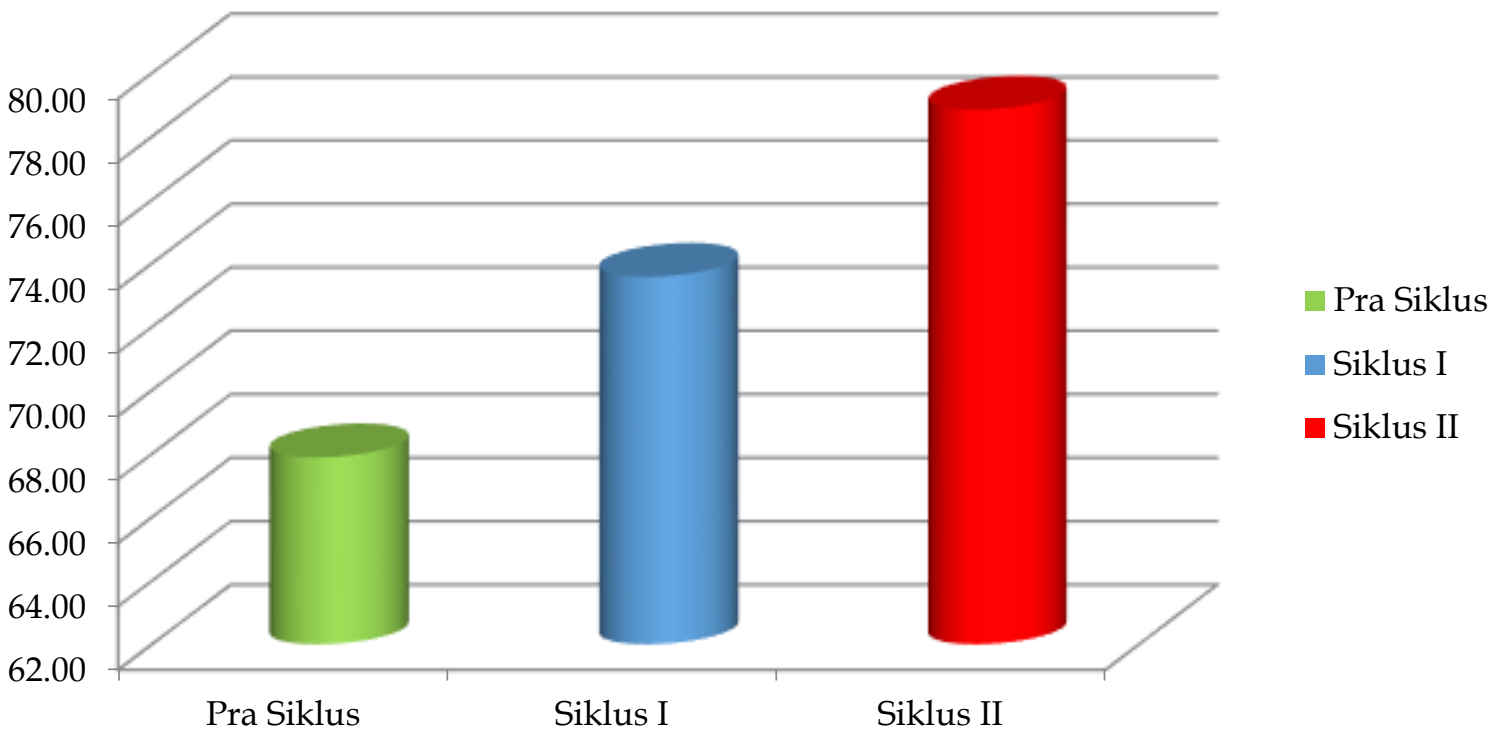

Gambar 1. Diagram Ketuntasan Belajar Pra Siklus, Siklus I, Siklus II

Dari hasil analisis tersebut dapat disimpulkan bahwa (1) terjadi peningkatan prestasi belajar siswa setelah diberi tindakan yaitu terjadi $67.88 \%$ menjadi $73.58 \%$ ada 
kenaikan sebesar $=5,70 \%$; (2) dari sebelum tindakan ( pra siklus ) dan setelah tindakan sampai dengan ( siklus 2 ) $67.88 \%$ menjadi $73.58 \%$ dan dari ( siklus 1 ) ke ( siklus 2) juga ada peningkatan sebanyak $80.95 \%$. - $73.58 \%=7,73 \%$; (3) rata-rata siswa sebelum diberi tindakan 67.88 , pada siklus I $=73.58$ dan pada siklus II $=80.96$.

Dari data rekapitulasi di atas dapat diketahui bahwa terjadi peningkatan nilai rata-rata hasil belajar siswa dari pra siklus sebesar 67,88 ke siklus I yang meningkat menjadi 73,58. Pada siklus II meningkat lagi sebesar 80,96. Berdasarkan data tersebut maka dapat diketahui bahwa pelaksanaan Penelitian Tindakan Kelas melalui model inquiry dan media diorama hasil belajar berhasil meningkat.

\section{KESIMPULAN}

Berdasarkan seluruh pembahasan serta analisis yang telah dilakukan dapat disimpulkan sebagai berikut (1) pembelajaran dengan menerapkan model pembelajaran inquiry dengan media diorama memiliki dampak positif dalam meningkatkan prestasi belajar siswa di SMP Negeri 1 Taliwang yang ditandai dengan peningkatan ketuntasan belajar siswa dalam setiap siklus, yaitu pra siklus $(67,88 \%)$, siklus I (73,58\%), dan siklus II (80,96\%); (2) Penerapan pembelajaran melalui model pembelajaran inquiry dengan media diorama mempunyai pengaruh positif, yaitu dapat meningkatkan prestasi belajar siswa dan; (3) Penerapan pembelajaran melalui model pembelajaran inquiry dengan media diorama sangat efektif untuk meningkatkan kembali materi ajar yang telah diterima siswa selama ini, sehingga mereka merasa siap untuk menghadapi pelajaran berikutnya.

\section{SARAN}

Dari hasil penelitian yang diperoleh dari uraian sebelumnya agar proses belajar mengajar di SMP Negeri 1 Taliwang lebih efektif dan lebih memberikan hasil yang optimal bagi siswa, maka disampaikan saran sebagai berikut (1) untuk melaksanakan model pembelajaran inquiry dengan media diorama memerlukan persiapan yang cukup matang, sehingga guru harus mempu menentukan atau memilih topik yang benar-benar bisa diterapkan sehingga diperoleh hasil yang optimal (2) guru hendaknya lebih sering melatih siswa dengan kegiatan penemuan, walau dalam taraf yang sederhana, di mana siswa nantinya dapat menemukan pengetahuan baru, memperoleh konsep dan keterampilan, sehingga siswa berhasil atau mampu memecahkan masalah-masalah yang dihadapinya; (3) perlu adanya penelitian yang lebih lanjut, karena hasil penelitian ini hanya dilakukan di SMP Negeri 1 Taliwang tahun pelajaran 2019-2020.

\section{UCAPAN TERIMAKASIH}

Penelitian ini tidak menerima hibah khusus dari agensi pendanaan mana pun di sektor publik, komersial, atau nirlaba.

\section{DAFTAR PUSTAKA}

Ahmad, S. (2013). Teori Belajar dan Pembelajaran di Sekolah Dasar. Jakarta: Kencana Prenadamedia Group Press.

Arikunto, S. (2002). Prosedur Penelitian Suatu Pendekatan Praktek. Jakarta: Rineksa Cipta Press.

Arikunto, S. (2007). Penelitian Tindakan Kelas. Bandung : remaja Rosdkaraya. 
Arikunto, S., Suhardjono \& Supardi. (2007). Penelitian Tindakan Kelas. Jakarta: Bumi Aksara Press.

Dimyati \& Mudjiono. (2002). Belajar dan Pembelajaran. Jakarta: Rineka Cipta dan Depdikbud.

Djamarah, S., B. (2002). Psikologi Belajar. Jakarta: Rineka Cipta.

Fathurrohman, M. (2017). Model-model pembelajaran Inovatif. Jogjakarta: Ar-Ruzz Media.

Ibrahim, M. (2003). Teori Belajar Konstruktivisme. Jakarta: Depdiknas.

Irham, M \& Novan, A. (2013). Psikologi Pendidikan Teori dan Aplikasi dalam Proses Pembelajaran. Yogyakarta: AR-RUZZ Media.

Margono. (2003). Metodologi Penelitian Pendidikan. Jakarta: Rineka Cipta

Meier, D. (2002). The Accelerated Learning Handbook. Jakarta: Mizan Pustaka

Musfiqun. (2012). Pengembangan Media dan Sumber Pembelajaran. Jakarta: PT. Prestasi Pustakaraya

Nasution S., (2001). Berbagai Pendekatan Dalam Proses Belajar Mengajar. Bina Aksara. Jakarta.

Nudhar, A., N. (2019). Peningkatan Hasil Belajar IPA Materi Siklus Air Menggunakan Model Inquiry dan Media Diorama Pada Siswa Kelas V MI Kumpulrejo 02 Salatiga Tahun Pelajaran 2018/2019. Skripsi. Jurusan PGMI IAIN Salatiga.

Poerwadarminta W.J.S. (2005). Kamus Umum Bahasa Indonesia. Jakarta: Balai Pustaka. Slameto. (1995). Belajar dan Faktor-Faktor Yang Mempengaruhinya. Rineka Cipta: Jakarta. Sudjana, N. (2001). Penilaian Hasil Proses Belajar Mengajar. PT Remaja Rosdakarya: Bandung.

Sagala. (2009). Konsep dan Makna Pembelajaran untuk Membantu Memecahkan Problematika Belajar dan Mengajar. Bandung: Alfabeta

Sanjaya, W. (2010). Strategi Pembelajaran Berorientasi Standar Proses Pendidikan. Jakarta: Kencana.

Slameto. (2003). Belajar dan Faktor-faktor yang Mempengaruhinya. Jakarta: Rineka Cipta Sugiyono. (2012). Metode Penelitian Kuantitatif Kualitatif dan REDD. Bandung: Alfabeta

Trianto. (2007). Model Pembelajaran Terpadu dalam Teori dan Praktek. Jakarta: Prestasi Pustaka.

Trianto. (2009). Mendesain Model Pembelajaran Inovatif Progresif. Surabaya: Kencana Trianto. (2010). Model Pembelajaran Terpadu. Surabaya: Bumi Aksara

Wijayanti, S. (2017). Peningkatan hasil belajar IPA materi Ciri-ciri Makhluk Hidup menggunakan Model Pembelajaran inquiry pada siswa kelas 21 III MI Darul 'Ulum Reksosari Kecamatan Suruh Kabupaten Semarang Tahun Pelajaran 2016/2017. Skripsi. Jurusan PGMI IAIN Salatiga. 